\title{
Public-private partnership in higher education provision in Tanzania: implications for access to and quality of education
}

\author{
Samson John Mgaiwa ${ }^{1 *}$ and Japhace Poncian²
}

*Correspondence:
mgaiwa12@gmail.com;
mgaiwa@muce.ac.tz
${ }^{1}$ Department of Educational
Planning and Administration,
Faculty of Education,
Mkwawa University College
of Education, P.O. Box 2512,
Iringa, Tanzania
Full list of author information
is available at the end of the
article

*Correspondence: mgaiwa12@gmail.com;

1 Department of Educational Planning and Administration Faculty of Education

Mkwawa University College

Full list of author information article

\begin{abstract}
Public-private partnerships (PPPs) in education are presented as capable of resolving several issues of education provision, financing, management, access and quality. This paper aimed at analyzing the impact of PPPs on access to and quality of higher education in Tanzania. Secondary research was used to gather data and critical review of the data and its analysis made. The focus of the paper was on higher education financing and on private higher education institutions. The findings indicated that PPPs have had a positive impact on increasing access to Tanzania higher education. However, although private universities and university colleges are many in number, enrolment has continued to be higher in public universities. It was further noted that an increase in higher learning institutions and subsequent increase in access to higher education has not meant an improvement in the quality of education provided by the institutions. As such, PPPs have had no significant impact on the improvement of quality of education. This is mainly accounted for by the number and qualifications held by academic members of staff in private universities, the infrastructure as well as the programmes they offer.
\end{abstract}

Keywords: Partnership, Tanzania, Access, Quality of education, University

\section{Background}

Education provision has been and continues to be one of the basic conditions for socioeconomic and technological transformations of any society. However, education provision at any level is not something that every society can easily afford because of the high costs involved. Recent developments in education and other social service sectors have taken this into account and countries, both developed and developing, have entered into partnerships with the private sector. Public-private partnerships in education provision, especially for developing countries, are encouraged because of the fact that many governments cannot adequately afford the costs of education provision due to economic position (Bray 1999). In this regard, public-private partnerships (PPP) has been identified as a viable means to effectively address constraints of financing, and management of education (URT 2009; Brans 2011; Patrinos and Sosale 2007).

Public-private partnerships in education entail a model of financing and education provision where public and private sectors share the costs and risks of education

(c) The Author(s) 2016. This article is distributed under the terms of the Creative Commons Attribution 4.0 International License (http://creativecommons.org/licenses/by/4.0/), which permits unrestricted use, distribution, and reproduction in any medium, provided you give appropriate credit to the original author(s) and the source, provide a link to the Creative Commons license, and indicate if changes were made. 
provision in a manner that involves 'a contracting mechanism used to acquire a specified service, of a defined quantity and quality, at an agreed-on price, from a specific provider, for a specific period (Taylor 2003 cited in Barrera-Osorio et al. 2009: 3-4). PPPs have the potential of enhancing service provision to both students and staff in higher learning institutions (United Republic of Tanzania 2010). Available scanty evidence in Africa show that private providers of education have helped to make education accessible to the poor in Sierra Leone and to the vast majority of the children in the Democratic Republic of Congo (Backiny-Yetna and Wodon 2009; Wodon and Ying 2009). In Tanzania, PPP in higher education has enabled the establishment of a number of private higher learning institutions which have provided opportunities to more than $30 \%$ of the total higher learning institutions' student population (TCU 2015b). These and other benefits are what make many believe public-private partnership can help solve challenges that the public mode of education provision face (Malik 2010; Mugabi 2012; Oketch 2003; Verger 2012). However, PPPs in education can only help make progress but are not a panacea to the several problems of education provision and financing (Bano 2008). In fact the proclaimed benefits of PPPs in education are increasingly questioned (Bano 2008; Brans 2011; Education International 2009). In the spirit of contributing to an emerging body of knowledge about PPPs in education, this paper examines the role and significance of PPPs on access to and quality of higher education in Tanzania.

The idea of public private partnership was brought about in the past two and half decades following the Tanzania's abandonment of socialist policies in the mid-1980s. Prior to this, higher education provision was a full responsibility of the state: there were no any private university or university colleges operating in the country during the socialist era. Beginning mid-1980s, the government started implementing a series of neoliberal informed reforms. These reforms aimed, among others, to appreciate the role of private sector in bringing about socio-economic development through investment in education. Despite earlier onset of neoliberal socio-economic and political reforms, higher education provision in Tanzania continued to be a state responsibility until 1995 when private provision of higher education was formerly introduced (United Republic of Tanzania 2010). Partnerships in education provision in Tanzania have mostly been being implemented by Faith Based Organizations (FBOs) (URT 2009). Majority of private higher learning institutions are owned and run by Faith Based Organisations. The Catholic Church, the Lutheran Church, the Seventh Adventist Church, the Anglican Church as well as Muslims are all owning and operating universities and university colleges. Given the fact that PPPs have been in practice in the education sector for quite some time now, it makes it imperative to take stock of the role this has played on access to and quality of higher education. The key argument of the paper is that PPPs have helped increase access to higher education although this has not meant that the quality of education provided has improved. The rest of the paper proceeds as follows. Section two describes the methodology adopted by this paper. Section three surveys the debates in the literature on PPPs in education following which some facts about Higher Education in Tanzania are provided. This is then followed by a discussion on PPPs and access to and quality of Higher Education in Tanzania. Finally, concluding remarks are provided. 


\section{Methods}

This paper used secondary research approach to make a critical analysis of the Public Private Partnership in higher education provision in Tanzania. Ellis et al. (2011) argue that secondary research is an approach in research and writing that seeks to describe and systematically analyse existing data from the available library sources in order to understand cultural experiences. Ideally, secondary analysis uses pre-existing data to investigate the research question at hand. Based on the kind of data, our analysis was therefore based on published educational data in light of the public private partnership. We defined access to higher education in terms of the number of students enrolled into higher education institutions and higher education infrastructure. This helped us ascertain how the government's move to fund higher education through the Higher Education Students' Loans Board (HESLB) and allow private operators provide higher education have increased opportunities for students to access higher education. We understand there are several forms of public-partnership but our focus in this paper was on higher education financing. In this case, we looked at government's financing of higher education through HESLB and its approach of working with the private sector in the provision of higher education.

We examined quality of higher education by looking at the quantity and qualifications of academic staff in higher education institutions and the capacity and role of the Tanzania Commission for Universities. We understand that there are several indicators of quality education which can be categorized into context, input, process, and output/ outcomes indicators (see Barnett 1992; Scheerens 2011). However, given our secondary research approach, it is not possible to get data for all indicators. As such, we chose to look at some aspects of the input and process indicators for which secondary data was available. We focused on staff number and qualifications for two obvious reasons: data about that is readily available and it is a basic input indicator that affects how well prepared the output (graduates in terms of their knowledge and skills) would be. The Tanzania Commission for Universities (TCU) requires that any higher education institution have a minimum of five academic staff with Ph.D. qualifications, five with Master's degree and 10 with Bachelor's degree (Graduate assistants) per each degree programme with a minimum of ten courses (TCU 2014: 6). However, graduate assistants do not lectures but rather they supervise tutorial, seminar presentations and practical., It also identifies that university teaching activities can only be conducted by staff with a master's and Ph.D. qualification for undergraduate programmes and staff with Ph.D. qualifications for postgraduate degree programmes (TCU 2014). By looking at the number and qualifications of academic staff, it was easier to deduce the impact of PPPs on the quality of education in universities and university colleges in Tanzania.

\section{Public-private partnership in education provision: a review}

Education provision is critical in any country's development. This being a fact, its provision has been facing several challenges, both in developing and developed countries. In late 2000s and early 2010s developed countries' education institutions started struggling to address the challenge of government budget cuts for education. Education budget cuts are now universal: governments across the world have been doing this for quite some time now (Awidi 2014). For example, due to the recent Global Economic and Financial 
Crisis, government budgets cuts of up to over $5 \%$ for education were made in almost 30 European countries in 2011 and/or 2012 (European Commission 2013). Coupled with budget cuts, education provision in developing countries continues to battle with other serious challenges especially related to quality of education provided and its capacity to absorb increasing demand for education (Awidi 2014; Grisay and Mählc 1991; Mugabi 2012; Oketch 2003). Commentators think public-private partnership in the provision of education can help solve many of the challenges that the public mode of education provision face (Malik 2010; Verger 2012).

Public-private partnerships (PPPs) broadly refer to work relations between the government and the private sector in the design and delivery of service which were previously a sole government responsibility. In the education context, PPPs have become influential and popularised by thinkers strategically affiliated with influential international institutions such as the World Bank, United Nations Education, Scientific and Cultural Organisation (UNESCO), the Asian Development Bank (ADB), World Economic Forum, International Finance Corporation (IFC), and the Centre for British Teachers (CfBT) (Verger 2012).

PPPs in education are very hard to define and the distinction between the public and private is not that much visible because the two sectors have always interacted in the provision of education (Robertson et al. 2012). In fact, there is a long history of private sector involvement in delivering public services, particularly in education. In many countries religious institutions established primary and secondary schools, or in some cases universities. In several countries such schools have been integrated into public systems. In countries like Tanzania, such schools were nationalised soon after independence following Tanzania's adoption of socialist policies (Chediel et al. 2000). In others, faith-based private schools have remained apart while receiving public subsidies and being subject to public regulation. In virtually all countries, public educational institutions provide a significant market for private suppliers of a range of services, from computers, textbooks and other learning materials, to canteen and cleaning services (Education International 2009: 10).

This notwithstanding, PPPs in education entail a recognition of a variety of options available for providing education besides public finance and public delivery (Patrinos et al. 2009: 1). It also entails contractual relations between the government and private providers to acquire education services at an agreed price for a specified period (CfBT 2008, WB 2009 cited in Verger 2012). This can involve government supporting the private sector and/or education entrepreneurs to actively participate in education organisation and delivery (Verger 2012; United Republic of Tanzania 1999). Tanzania, for example, has chosen a PPP modality where the state guides policy and funds higher education provision through a state funded HESLB which provides loans to means tested students in both public and private universities and university colleges to cover for fees and other costs. With this modality, the private sector is allowed to establish, own and operate higher education institutions as well as offer higher education programmes of their choice. Similarly, private higher learning institutions are also expected to supplement government initiatives and demand for particular academic and/or professional programmes. This is why, in Tanzania, many private higher education institutions offer bachelor degree programmes in education (science or arts) following government's high 
demand for trained teachers for its secondary schools. In this sense, private provision of education in Tanzania, like elsewhere in East and the rest of Africa, has been demand driven (Mugabi 2012) as higher education institutions are increasingly seen more and more like business enterprises (Sall 2004).

PPPs require that the role of the state be redefined to accommodate the changes and provide space for the private sector's role in the provision of education. Arguably, the role of the state should be that of steering rather than rowing educational services; that is the state should focus on 'the strategic control, funding, and planning of the education system' (Verger 2012: 118). In line with this argument, the National Higher Education Policy of Tanzania clearly stated the role of the state to be supervision, regulation, guidance and provision of incentives for higher education institutions (United Republic of Tanzania 1999).

Supporters of PPPs in education argue their case based on a number of potential (real and perceived) benefits that implementing countries stand to gain. For example, PPPs are touted as ideal for complementing government efforts and assisting developing countries meet their international agreements commitments, improve learning outcomes, provide alternative education financing options, etc. (Patrinos et al. 2009; Verger 2012). Other benefits associated with PPPs in education include taking advantage of specialised skills in the private sector; overcoming operating restrictions; permitting economies of scale; allowing governments to respond to new demands and facilitate adoption of innovations in service delivery; allowing governments to focus on those functions for which they are comparatively advantaged; increasing transparency of government spending; overcoming constraints on public budgets; and mobilising resources in the absence of effective systems for collecting revenue (Education International 2009).

Emerging empirical studies also provide insights into what PPPs in education can achieve. A recent empirical study on PPP in education in Punjab, India shows that PPPs in education have greater positive impact on education quality, access and overall improvement of human resources (Malik 2010).

The Punjab Education Foundation's (PEF) flagship initiative, the Foundation-Assisted Schools program (FAS ), has shown that better and affordable quality education can be had at a lesser cost through PPPs. Participating private schools are now providing quality education in underprivileged urban, suburban, and remote rural areas. At the private schools selected by the FAS programme, the students have on average scored higher in the QATs (quality assurance test) every year, with the proportion of students scoring over $90 \%$-rising from about $1 \%$ to almost $18 \%$ in only 4 years. More startling, the dropout rate at FAS partner schools is now zero, an exemplary accomplishment considering that the overall dropout rate in Pakistan schools is $40 \%$ by Grade 4 and $77 \%$ by Grade 10 (Malik 2010: 27).

These empirical findings from India give credence to an argument that PPPs in education are critical for ensuring and maintaining quality of education, and making education provision respond to the needs and conditions of the poor (Patrinos and Sosale 2007). In Latin America, poor resources and quality of education have made PPPs a regular policy option with public financing of 'private' education institutions making it possible for the less privileged and the poor to have access to relatively good quality education provided by private providers (Mora 2007). Furthermore, PPP in higher education provision is beneficial because private higher education providers. 
... can award more than just degrees. They have also filled some of the demand for higher education and, as noted, have proved to be more accountable and efficient in their management (...). They have acted as examples of innovation in higher education to the financially trapped and rigid public universities (Oketch 2003: 28).

Despite all these potential benefits and emerging empirical evidence to support PPPs in education, critics believe PPPs in education is just nothing but the privatisation of education (Brans 2011; Education International 2009). Furthermore, critics argue that despite the supposed benefits used to defend PPPs, the debate around the concept remain entrenched in ideological discourse where, in the developing countries, the focus is on the inability of the state to provide an adequate and acceptable level of education as well as issues of corruption; thus using PPPs to promote the private sector, the market economy and western interests (Education International 2009; Brock-Utne 2003). Along this line of argument, one would add that PPPs in education are just a means of creating opportunities for the private sector to have access to public funds. This might be true in Tanzania, for example, where, private providers of higher education have increased in number following the government's move to fund higher education through HESLB. The fact that almost all private universities and university colleges offer bachelor degree programmes in education (which is a government priority area for those who want to access loans) gives more credence to this claim. As we shall see below and as one scholar argues, private provision of higher education comes with several weaknesses in that it is 'often ad hoc, sporadic, and geared towards short-term gains with little regard for issues such as basic research, the long-term reproduction of the scholarly community, and academic freedom' (Sall 2004: 203).

Nevertheless, PPPs continue to be important in the provision of education especially so in developing countries where their practice hasn't been adequately studied (Patrinos and Sosale 2007). Because PPPs will continue influencing education policy and practice, generating evidence from developing countries on the performance and impact of PPPs in education is important. This will help inform improvements in the conceptualisation and application of PPPs in education development and delivery.

\section{Basic facts about higher education and PPP in Tanzania's higher education}

The history of higher education in Tanzania can be traced back in the last five decades (1961) where the University of Dar es Salaam was established as a constituent College of the University of London. In 1970, the University of Dar es Salaam became an independent institution, being the only higher education institution in the country enrolling 3000 students during its first 10 years of operation (Coulson 1982 cited in Johnson 2011). In 1984, the then Faculty of Agriculture, Forestry and Veterinary Sciences of the University of Dar es Salaam was upgraded into a full-fledged Sokoine University of Agriculture through a parliamentary Act number 6 of 1984 (Sokoine University of Agriculture 2016). This made the number of higher learning institutions in the country to be two. During the period from 1960 to 1980s, higher education was greatly influenced and/or affected by the socialist ideology. For example, following the Musoma Resolution of 1974, student admissions into higher education were to be made subject to the condition that the applicants had to have served into public service or national service for some time; this resulted in higher education institutions being transformed into institutions serving the workers and peasants (Biswalo 1985). 
As indicated earlier, higher education provision remained solely a government's responsibility from independence to the mid-1990s. Beginning the mid-1980s, Tanzania began implementing a series of neoliberal socio-economic and political reforms in line with what was happening elsewhere in Africa and beyond. This was a response to serious economic challenges the country faced during the time. These challenges had their ramifications on higher education provision and access. For example, due to economic crisis, enrolment of students into the country's two universities remained low: in 1990 there were 3146 students enrolled at University of Dar es Salaam and Sokoine University of Agriculture (compared to 3000 who were enrolled at the University of Dar es Salaam early 1980s) (Mkude et al. 2003: 63). Access to higher education continued to be a daunting challenge, more so to females as female students enrolled into higher education continued to comprise a small proportion of between 10 and 20\% during the 1990s (Luhanga 2009 cited in Johnson 2011: 11).

As the public provision of higher education in Tanzania could not keep pace with growing challenges and increase enrolment, the government decided to engage the private sector in the provision of higher education. The involvement of the private sector in higher education provision was a result of the government's realization that publicprivate partnership in education provision is '... necessary and a matter that requires encouragement' (United Republic of Tanzania 2010: 17). As such, in 1995 the government formulated the Education and Training Policy which redefined the role of the government and provided opportunities for the private sector to participate in education provision at all levels. On a specific note, the government further formulated a Higher Education Policy in 1999 to, among others, encourage and assist the establishment of private and public higher education institutions (United Republic of Tanzania 1999). Significant to PPP, the policy stated clearly that, The State and institutions of higher education shall have a contractual relationship such that the State shall give a clear mandate to higher education institutions, indicating clearly the expected outputs and proposed inputs (United Republic of Tanzania 1999: 12).

Following this policy and ideological shift, it is not surprising that the number of private higher education providers has increased from just zero in 1990s to over 60 now. This increase in the number of higher education institutions has also meant a tremendous increase in the number of students enrolled: from just 5001 in 1995/96 to 40,993 in 2005/06 (Mkude et al. 2003: 63; United Republic of Tanzania 2010: 23). Most recent data shows that the number of students enrolled into universities and university colleges was 218,959 in 2013/14 with private universities and university colleges accounting for $34.2 \%$ of the total enrolment (TCU 2015b).

Most recent data shows that Tanzania has a total of 71 higher education institutions as of February 2016 (TCU 2016a). These comprise of 12 public universities, 21 private universities, two public university colleges, 14 private university colleges, five public and 17 private university campuses/centres/institutes.

Also significant has been the establishment of the Higher Education Students' Loans Board (HESLB) which oversees government funding of higher education. By this, students enrolled in degree offering private and public higher learning institutions and who have been means tested by the board receive loans to cover for their fees and stipend on a cost sharing basis. Loans are especially provided to students enrolled into programmes 
such as science, education and technology which are considered by the government as being of priority. This explains why many private universities and university colleges offer bachelor degrees in education programmes (mainly in social sciences and humanities teaching disciplines) and enroll a large number of students into such degrees, presumably to get access to public funds through HESLB. Despite the fact that private universities are more in number compared to public higher education institutions, a greater proportion of students are enrolled into public universities and university colleges. In 2006/07 for instance, public universities enrolled 78.4 percent of the total students (Ishengoma 2007; TCU 2015a; Mgaiwa 2015). Enrollment in private universities continues to be as low as $21.5 \%$ of the total student population.

The implementation of liberalisation policies and the subsequent rapid increase in the number of higher education institutions in Tanzania has raised concerns over the quality of education. Some scholars are skeptical of the quality of education provided in the mushrooming private universities and university colleges throughout the country (see for example, Ishengoma 2007; Makulilo 2012). These, however, have studied the phenomenon from the perspective of education privatization and do not, therefore, look at the aspect of PPP.

As noted earlier, public private partnership may be defined in several ways. We define public private partnership as the partnership or collaboration and division of labour between the public and private sectors across policy spheres as well as on particular projects (Linder and Rosenau 2000). It is a 'rubric for describing cooperative ventures between the state and private business...' (Linder and Rosenau 2000: 19). On this basis, public-private partnership in education in this paper is understood as the collaboration between the state and the private sector in the delivery of education. Since there are many forms of PPPs in education (Patrinos et al. 2009), this paper focuses mainly on the aspect of higher education financing where the government of Tanzania finances and delivers higher education (in its public institutions) and the private sector co-delivers education. Many higher education students in Tanzania pay for their university education costs through loans from the Higher Education Student Loans Board (HESLB). Other forms of partnership in Tanzania's higher education are touched on lightly here (see below). This is because it is difficult to establish their consequences on quality of education using the secondary research approach that this paper adopted.

HESLB was established under Act No. 9 of 2004 and commenced operations in July, 2005 (Higher Education Students' Loans Board 2016). It is a government funded agency established to oversee the issuance and collection of loans to higher education students. It was established to provide loans to qualified and needy students so they can access higher education regardless of whether they are enrolled into public or private universities (Nyahende 2013). This followed a realization that it was increasingly becoming impossible for the government to freely provide higher education (Rugambuka 2008). HESLB provides loans on a cost sharing basis as 'a shift in shouldering at least part of the costs of education from the Government, which had hitherto been the main financier to the beneficiaries' (Higher Education Students' Loans Board 2016: 1). The aim of doing this is 'to increase participation and accessibility to all institutions of higher education' (Rugambuka 2008: 17). The introduction of cost sharing policies and subsequent 
establishment of the loans board coincided with government's socio-economic reforms which saw the private sector becoming important in higher education provision.

We consider government financing of higher education through HESLB as a case of public-private partnership in higher education provision for a number of reasons. In the first place, the government through HESLB finances higher education provision by providing loans to needy and qualified students enrolled into higher learning institutions and disbursing student loans to tuition dependent private universities throughout the country. This provides much needed financial resources for emerging private higher education institutions which, in the context of a poor country like Tanzania, would otherwise not be able to outsmart the public universities and university colleges. Secondly, that HESLB provides loans on a cost sharing basis and requires loan beneficiaries to repay after they have graduated makes it a true case of public-private partnership. It makes higher education provision not a service whose costs should entirely be borne by the government like it used to be during the pre-liberalisation era. Instead, higher education provision and financing becomes a shared responsibility between the public sector and the private individuals (loan beneficiaries, their parents, etc.). Thirdly, government financing of higher education through HESLB makes higher education provision a shared responsibility between the government and the private sector as opposed to previous arrangements when higher education provision was mainly a responsibility of the state. As such, several higher education institutions owned and operated by the private sector have sprung up in response to higher education policy changes and government's commitment to provide loans to needy and qualified students enrolled into such institutions. In this sense, the government plays the role of both providing (for public higher learning institutions) and financing higher education, as well as regulating the provision of the same. The private sector and/or individuals play the role of establishing and running higher education institutions so they can work together with the government in providing higher education. Although one may argue that HESLB does not necessarily make loan provision an aspect of public-private partnership because loans are given to students and they are bound to repay them after their studies, the fact that the board is funded and operated by the government and provides loans to bonafide students in both public and private institutions makes it a proper case of PPP in higher education, at least in the context of Tanzania. Taking all this in consideration, this paper, as stated earlier, looks at the impact this form of partnership has had on access to and quality of higher education in Tanzania.

As mentioned above, another type of partnership that exists in Tanzania is that of infrastructure ownership transfer. This is obvious in the provision of higher education in Tanzania where one partner builds and transfers the ownership to another partner to operate and manage an institution. For instance the government transferred the ownership of its three institutions to the private sector to operate and manage. These institutions include the then Tanzania Electric Supply Company (TANESCO) training institute which the then president of Tanzania, His Excellency Benjamin Mkapa, granted in 2004, to the Muslim Development Foundation (MDF) to establish the Muslim University of Morogoro (Njozi 2016). Another example is the former Mazengo Secondary School which was nationalised in the late 1960s from the Anglican Church. In 2005, the school was given back to the Anglican Church to establish a university which has become 
known as St. John's University of Tanzania (SJUT) (SJUT 2009). Similarly, what used to be a government banking institution, the Dr. Amon J. Nsekela Bankers' Academy was granted to the Roman Catholic Church which then used it to open the Ruaha University College, a constituent college of the St. Augustine University of Tanzania in 2005. The university college was recently upgraded to a full-fledged university, the Ruaha Catholic University (RUCU). Although this form of partnership must have had an impact on access to and quality of education (for example increasing opportunities for students to get enrolled into university education), the focus of this paper is on the financing of higher education through HESLB.

\section{Results and discussion}

In this section findings on the impact of public-private partnership in education, focusing on the impact of PPPs on access to higher education and quality of the same on the sub sector are presented. The discussion is made in line with views from other similar studies with global perspective.

\section{Impact of PPPs on access to education}

The analysis made from 2007 to 2014 indicated that PPPs have contributed to increasing access to higher education sub sector by increasing both the number of institutions and students hence rise in enrolment rate as indicated in Table 1.

Comparatively as it is indicated in Table 1 , private universities and university colleges have been playing a minimal role in creating education opportunities compared to public universities. Empirical evidence from Table 1 indicate generally that private universities for the past 7 years have enrolled between 24 and $35 \%$ of the entire students' enrollment. This is despite the fact that the number of private universities and university colleges is higher than that of public universities and university colleges. Of the 33 universities, only 12 universities (36.4\%) are public and 21 (63.4\%) are private; of the 16 university colleges only two (12.5\%) are public and $14(87.5 \%)$ are private; and out of 22 university centres/institutes/campuses only five (22.7\%) are public while the rest 17 (77.3\%) are private (TCU 2015b). This shows that the private higher education sector has grown tremendously in the past few decades although its role remains minimal. Until 2013/2014 private universities enrolled only $34.1 \%$ of the total students enrolled in the higher education sub sector. Compared to their number this is a minimal enrolment rate compared to public universities, university colleges and centres which enrolled $65.8 \%$

Table 1 Enrolment trend in Universities and University Colleges 2007/08-2013/14

\begin{tabular}{llcr}
\hline Year & Private institutions & Public institutions & \multicolumn{1}{c}{ Total } \\
\hline $2007 / 2008$ & $19,239(24.8)$ & $58,307(75.2 \%)$ & 77,546 \\
$2008 / 2009$ & $26,808(27.4 \%)$ & $70,785(72.6 \%)$ & 97,593 \\
$2009 / 2010$ & $37,825(31 \%)$ & $83,828(69 \%)$ & 121,653 \\
$2010 / 2011$ & $38,695(27 \%)$ & $104,130(73 \%)$ & 142,825 \\
$2011 / 2012$ & $55,906(32.8 \%)$ & $114,531(67.2 \%)$ & 170,437 \\
$2012 / 2013$ & $71,861(35.5 \%)$ & $129,125(64.5 \%)$ & 200,986 \\
$2013 / 2014$ & $74,802(34.1 \%)$ & $144,157(65.9 \%)$ & 218,959 \\
\hline
\end{tabular}

United Republic of Tanzania 2014 
of the total students in the country. This notwithstanding, however, their existence has helped provide opportunities for up to $35 \%$ of university students to access university education, and based on this it becomes clear that private higher education institutions have played a role that cannot just be sidelined. They are certainly part of the reason for the increase in university student enrolment from just 30,759 in 2003 to 115, 305 in 2009 (UNESCO 2011: 84). This contribution mirrors what is going on in other East African countries regarding the role of private higher learning institutions in creating opportunities for access to higher education. In Uganda, for example, despite being many, private universities, enroll about 30\% of university students (Mugabi 2012). Generally, what appears from this data, like elsewhere in African, public universities continue to be significant in terms of student enrolment in spite of being fewer in number compared to private universities (Munene 2009).

Despite the minimal role played by private higher education institutions, these findings indicate that PPPs have increased students' enrolment in universities by $64.5 \%$ in the last seven years. Furthermore, PPPs can also be associated with an increase in the gross enrollment rate in the past two decades. For example, the gross enrolment rate increased from 3\% in 2008/2009 to 4.2 percent in 2014/2015 (TCU 2016b). Further, looking at enrolment in terms of gender, private universities and universities appear to create more opportunities for female students than it is in the public universities. For example, admission statistics from TCU show that while female student enrolment in public universities was ranged between 32 and 34\%, in private universities it stood at between 40 and $42 \%$ of total enrolment during the period from 2009/10 to 2013/14 (TCU 2015b). This suggests that private sector involvement in provision of higher education helps, at least in the Tanzanian context, to reduce the gender gap in higher education student enrolments.

Despite the progress made so far, the enrolment ratio still remains low at 3.9\% particularly when compared with the gross enrolment ratio (GER) of $51.6 \%$ in the developed world (Varghese 2004 p. 9). This clearly indicates that the role of private higher learning institutions in increasing access to university education remains minimal. This becomes more compelling when one considers the programmes that private higher learning institutions offer. As noted earlier, most private higher learning institutions are much into offering bachelor degrees in education programmes thereby limiting opportunities for access to non-education degree programmes. Student enrollment into education programmes (both in arts and science subjects) has increased from just 11,058 in 2006/07 to 82,038 in 2013/14 (TCUno date). It should be borne in mind that this rapid increase in student enrollment into education programmes happened at the same time when many university colleges and centres owned by private operators were established, and precisely after HESLB commenced its operations. Even looking into the contents of the programmes themselves, one wonders whether private universities and university colleges really improve access to an education that is a bit different and better than that in public universities. Our experience teaching as part time lecturers in some of the private university colleges shows that in many of these institutions, degree programmes and courses offered are just a copy and paste of those offered at the University of Dar es Salaam; what they change are the course codes only. Yes, access to higher education in terms of enrollment has increased but looking at numbers alone hides many other details such as 
the diversity of programmes offered and the uniqueness of courses taught in the private universities and university colleges which are also significant when it comes to access to higher education. As such, there isn't much of innovation in terms of programme and course design that one would expect of a private higher learning institution.

\section{Educational infrastructure development and quality of education}

Prior to PPPs, educational infrastructure development was the sole responsibility of the government, but today as a result of PPPs this has been the shared responsibility between the institutions on one hand and the direct beneficiaries of such education. Due to inability of the government in investing in educational infrastructure like lecture theatres, laboratories and libraries as part of increasing access to higher education, PPP arrangements have helped bring in private investors in higher education infrastructure which has had an impact in increasing student enrolment in higher education sub sector. There are notable examples of educational infrastructure built by private institutions and international institutions for example at Business School of University of Dar es Salaam, Sokoine University of Agriculture, University of Dodoma and Nelson Mandela African Institute for Science and Technology. Another notable example as mentioned earlier is the government's granting of its own built infrastructure to private operators. The granting of such infrastructure to private faith based organisations in Morogoro, Dodoma and Iringa enabled the establishment of three universities, namely, the Muslim University of Morogoro, St. John's University of Tanzania, and Ruaha Catholic University respectively.

\section{Impact of PPPs on quality of higher education}

Findings on the impact of PPPs on education quality indicates that the implementation of PPPs in Tanzania higher education has had an impact on the quality of education provided by the private sub sector. Scholars agree at some point that the quality dimension of education is better seen when the education system is viewed as a complex manufacturing industry with inputs, process and outputs (Scheerens 2011). Based on this conception of education, input and the quality of the process are what determine the quality of outputs or graduates. As we could not get data about the output indicator of quality because of our research design, our discussion here focuses on inputs (number and qualifications of academic staff) and partly on the process indicator (teaching and learning).

\section{Teaching staff and their impact on quality of education}

Teaching staff and their education qualifications is one of the key determinants of quality of education as well as their excellence in research and publications. Empirical evidence collected from the existing literature and from primary documents from Tanzania Commission for Universities (TCU) shows that the number and quality of teaching staff is questionable. For a university to be said of quality, it is required to have a minimum of five academic staff with Ph.D. qualifications, five with Master's degree and 10 with bachelor's degree per each degree programme with a minimum of ten courses (TCU 2014: 6). Evidence reveal that most private universities and university colleges and centres have very few staff with PhDs. Majority of the academic staff in these universities and university colleges and centres have masters and bachelor degrees. Findings on Private Universities' staff qualifications are indicated in Table 2 below. 


\begin{tabular}{lcccc}
$\begin{array}{l}\text { Table } 2 \text { Academic Staff } \\
\text { and University Colleges }\end{array}$ & qualifications, and Sex in & non-government & Universities \\
\hline Qualification & M & F & T & Percent (\%) \\
\hline Post Graduate Certificate & 51 & 21 & 72 & 2.9 \\
Post Graduate Diploma & 44 & 11 & 55 & 2.2 \\
Bachelor Degree & 304 & 134 & 438 & 18.1 \\
Masters & 872 & 346 & 1218 & 50.3 \\
Doctorate (PhD) & 522 & 112 & 634 & 26.2 \\
Grand total & & & 2417 & 100.0 \\
\hline
\end{tabular}

TCU (2015a)

Table 2 shows that, only $26 \%$ of the total members of academic staff in private universities have academic qualifications which are prerequisite for one to become academic staff in a university. This suggests that most private universities in Tanzania have no adequate quality inputs in terms of qualified academic members of staff. Empirical evidence also from other studies in Tanzania have indicated similar findings from private universities (Ishengoma 2007; Simon 2010; Makulilo 2012; Mgaiwa 2015). This indicates further that university staff in Tanzania private universities and university colleges have low academic profile as per requirement of the TCU. The situation was even more critical in the year 2005/06 where private universities had only 2 professors, 10 assistant professors, 24 senior lecturers, 45 lecturers, 14 assistant lecturers, and 11 tutorial assistants compared to public universities which had 113 professors, 214 assistant professors, 367 senior lecturers, 359 lecturers, 476 assistant lecturers and 117 tutorial assistants (UNESCO 2011: 395).

This implies that private universities in Tanzania are of low quality given the fact that quality of academic members of staff is one of the basic requirement. Some scholars argue that investment of universities in institutional staffing is very little because of profit driven motives (Ishengoma 2007; Brans 2011; Alexander et al. 2014). Some universities have been established without adequate academic staff because of profit motives, hence affecting the quality of education provided. Requirements by TCU for establishing a university and for it to be accredited as mentioned in section two above are rarely met by many private universities. Academic staff qualification is still a topical issue in Tanzania as findings by Simon (2010) on academic staff capacities in private universities in Tanzania found that $90.2 \%$ of academic staff in these private universities and university colleges were holders of masters and first degrees with only nine (9) percent holding Ph.D.s. A further look at academic staff information as contained in prospectuses of some of the private higher education institutions reveals this clearly. As a general rule, postgraduate students (master's and Ph.D. students) can only be taught and supervised by senior academic staff with a Ph.D. qualification. It would therefore be expected that any institution that offers postgraduate programmes would a have a good number of academic staff qualified in disciplines offering such degrees. However, as Table 3 below shows, this does not seem to be the case.

As can be deduced from the Table above, it is apparent that many universities and university colleges offering postgraduate degrees do not have adequate number of qualified staff to run the programmes. This means that the private higher learning institutions establish and run postgraduate programmes when they have a number of qualified 
Table 3 Number of academic staff with Ph.D. qualification in some private higher learning institutions offering Master's Degrees in education

\begin{tabular}{ll}
\hline Higher education institution & No. of Qualified Staff with a Ph.D. \\
\hline Ruaha Catholic University (RUCU) & 3 \\
St. John's University of Tanzania (SJUT) $^{\text {a }}$ & 2 \\
Teofilo Kisanji University (TEKU) $^{\mathrm{a}}$ & 2 \\
University of Bagamoyo (UoB) $^{\mathrm{b}}$ & 2 \\
Sebastian Kolowa Memorial University (SEKOMU $_{\text {Archbishop Mihayo University College of Tabora (AMUCTA) }}^{\mathrm{c}}$ & 3 \\
\hline
\end{tabular}

Authors' compilation based on information from university prospectuses of RUCU (2014), SJUT (2014), TEKU (2015), SEKOMU (2014), AMUCTA (2015), and http://www.uob.ac.tz/index.php/2015-03-23-08-45-42/college-of-education

These universities and university colleges offer many other postgraduate degrees but we chose only master's degrees in education as a representative because they are offered in most of the institutions. Common master degrees in education in these institutions include Master of Arts in Education, Master of Education in Special Education, Master of Education Management and Planning, etc

a The institution's postgraduate prospectus lists 13 academic staff with PhDs but only two of them appear to be employed by TEKU. The rest are employees of other higher learning institutions

b There are only two permanent staff with requisite qualifications; the rest are part time staff employed elsewhere in other institutions

c There are four listed academic staff with PhDs. However, two of the four staff are employees of the University of Dar es Salaam Mulokozi ( 2012)

academic staff members that is below the TCU's minimum requirement of at least five academic staff with PhD qualification per each degree programme in offer. In many of these universities and university colleges, postgraduate students are taught and supervised by part time staff from other institutions, mostly from the University of Dar es Salaam. This means that without the University of Dar es Salaam and other established public universities, these private universities and university colleges cannot be able to run their programmes. As Sall (2004: 203) 'without the traditional higher education institutions, specifically the public university, many of the private institutions that exist in Africa today would not survive'.

As part time staff have their busy schedules and other students to supervise at their parent institutions, one wonders to what extent they can provide adequate teaching and supervision to postgraduate students in the private institutions. As Makulilo (2012: 55) argues, private universities and university colleges' reliance on part time lecturers hampers the quality of education provided because part time lecturers are 'never looking for improving quality of education rather extra money for a living. In many such universities and university colleges, the number of admitted students into postgraduate programmes far outweighs the number of qualified staff available to teach and supervise the students. Ruaha Catholic University (RUCU) has three academic staff with a Ph.D. qualification but admitted 54 students into Master of Education in Planning and Administration (MEPA) and 25 students into Master of Education in Curriculum and Instruction (MECI) programmes during the 2015/2016 academic year (RUCU 2015). Training all these students to required standards and ensuring that the programmes offered result into quality graduates in circumstances where the university has only three qualified academic staff in that field of study is very questionable.

In some institutions, one finds that academic staff teach and supervise students in areas which do not match with their PhD specialisation. A good example is the Archbishop Mihayo University College of Tabora (AMUCTA) which offers a Master's degree 
in Educational Management and Planning. Of the four listed staff, only two have a Ph.D. in education. The rest have their Ph.D. qualification in non-education disciplines, yet they are expected to teach and supervise master's students. Even those with their Ph.D. in education, their specialisation does not seem to match well with the Master's programme offered. It remains questionable how a staff with a Ph.D. in Curriculum and Instruction would provide relevant and expert teaching and supervision to a master's student researching on issues of educational management and planning. In such conditions, it is hard to expect high quality graduates from such universities and university colleges. What is more surprising is that these higher learning institutions are sanctioned by TCU to offer postgraduate programmes when they do not have adequate and qualified staff.

Generally, there is a concentration of faculty members in the lower ranks than in the higher and more qualified ranks. These findings give a picture that PPPs in higher education have promoted an increase in the number of higher education institutions as well as students but have not been able to promote quality education provision through the recruitment of enough qualified academic staff. While supporters of PPP in higher education argue their case that including the private sector in the provision of higher education would enhance access to quality higher education, accountability, innovation and efficiency (Mugabi 2012; Oketch 2003), this does not seem to be the case in Tanzania.

\section{Institutional educational infrastructure and quality of education}

Quality of education can also be measured by other parameters such as educational infrastructure that also determine the quality of teaching in universities. The current PPP arrangement in Tanzania higher education is such that the private sector builds and operate the institutions while the public sector, among others, finances higher education through students' loans after admission to universities. The amount funding to an institution on the other hand is determined by number of needy and qualified students an institution has admitted. Due to profit motives held by some institutions, some universities have found themselves admitting more students than their admission capacity of the existing infrastructure requirement consequently posing adverse negative impact on the quality of teaching and subsequently the quality of education offered in higher education institutions. Instead of doing their business in manner that challenges the common practice in public universities, private universities find themselves doing things more or less similar to public universities. For instance Fig. 1 shows a clear case in one of the universities in Tanzania where the number of students extremely exceeds the lecture room carrying capacity such that some are seated while others standing outside.

With this situation presented in Fig. 1, it is clear that the teaching and learning process cannot be judged to be of expected standards and therefore the education provided may not be of requisite quality. The limited size of lecture halls hinders the delivery of lectures as not all the students get what their instructors intend and if so, the learners acquire in aggregate little of what they could get in quality and accommodating class. This has a tremendous effect to students' learning. Studies also show that in many African countries, academic standards have been falling rapidly because some universities lack the basic infrastructure needed to cope with massive growth in the student population especially when admission exceeds infrastructure carrying capacity (Konings 2002). 


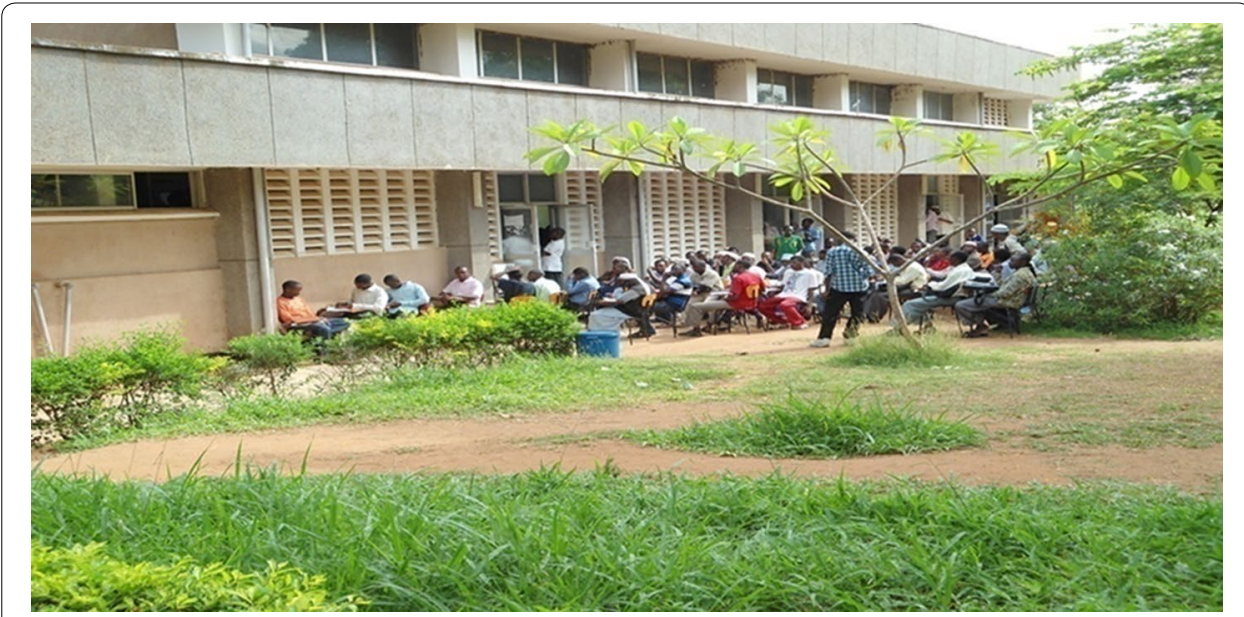

Fig. 1 Students attending lecture at one of the Universities in Tanzania

While it would be expected that private providers of higher education would do more to put in place adequate infrastructure for teaching and learning because they have more resources than the public sector, PPP in higher education in Tanzania does not seem to bring anything better in terms of education quality.

\section{Financing of education under PPPs and quality of education}

The state financing of students to both public and private universities is also determined by priority programmes such as medical profession, engineering, education and agriculture such that many universities are compelled to establish programmes of priority for funding without adequate account of university staffing, ability of students admitted to the programme and infrastructure capacity to accommodate such programmes. Given this, it is not surprising that some universities have sprung up only to offer one or two degree programmes for which funding is readily available. A good example is the Eckernforde Tanga University (ETU) which only offers two bachelor degree programmes, namely Bachelor of Arts with Education (BAED) and Bachelor of Business Administration (ETU 2016; TCU 2016c). In this case, it is obvious that the intention is not to improve access to and quality of higher education but to tap public financial resources made available through HESLB.

Of recent the Tanzania Commission for Universities (TCU) as a regulatory body closed one university for failing to meet the standards in terms of staffing and infrastructure. In addition to that, TCU disqualified fifty-three (53) students for being admitted without adequate qualifications at St. John's University, Arusha campus (TCU 2015b). Moreover, 489 students were expelled from St. Joseph University of Tanzania for lacking requisite admission qualifications as they had failed in their secondary education (Machira 2016). Arguably, this could be associated with universities admitting more students to the extent of even admitting unqualified ones for the sake of getting more funds via admitted students under government sponsorship. Although there is no data on how many such unqualified students found their way into the universities and have graduated, it is probable that in the past many such students might have been admitted, offered loans and successfully graduated and are now working as teachers in various secondary schools 
throughout the country. It is clear that such kind of programme established under this environment cannot be able to produce quality and employable graduates.

It is unfortunate that some public universities have also been found to admit students lacking adequate entry qualifications. At the University of Dodoma, for example, students pursuing a special diploma programme in science were also suspended by ministry responsible for education, science, technology and vocational training for not meeting the admission criteria though they were already at the university and in different years of study and had received loans from HESLB. A review made by the ministry has revealed that a total of 290 students were admitted into the special diploma in science education at the University of Dodoma without meeting the entry qualifications (Ministry of Education, Science and Technology 2016).

\section{Regulatory bodies and quality of education}

In Tanzania a national quality assurance organ was established effectively in 1995 following the government's acceptance to allow private higher education providers. The focus was, among others, on the accreditation of private universities in Tanzania. Following this idea, the Higher Education Accreditation Council (HEAC) was established in the same year with the legal mandate to regulate the establishment and subsequent accreditation of private university institutions in the country (Ishengoma 2007; Mgaiwa 2015). Such mandate was limited only to private universities (Kuhanga 2006). This was seen to be unfavorable for the promotion of a viable public-private partnership in higher education as stipulated in the National Higher Education Policy of 1999. Therefore, there was need to establish a harmonized higher education system in the country. This led to the establishment of the Tanzania Commission for Universities (TCU) constituted by the Universities Act No.7 of 2005 so that it could oversee and regulate both public and private universities in the country (TCU 2012).

Despite this good move made by the government to ensure there is quality of education provided in higher education, the role of Tanzania Commission for Universities has been questioned by many stakeholders and particularly regarding how the universities are established and the way accreditation process is conducted. For example, it is surprising to see that TCU accredits universities and university colleges that do not have adequate qualified academic staff. Our experience as part time staff in some of the private universities and university colleges made us realise that Tutorial Assistants (academic staff with a bachelor's degree) are assigned undergraduate courses to teach and evaluate student progress without any formal supervision. This is contrary to TCU provisions which do not provide for Tutorial Assistants to engage in undergraduate teaching (TCU 2014). Together with this, the quality of graduates from these universities is also constantly questioned by stakeholders of higher education. All these cast doubt on the capacity of TCU to ensure that higher learning institutions adhere to established benchmarks and standards.

\section{Policy implications}

The increase of higher education institutions which has been a result of public private partnership need to be translated into the increase of access to and quality of education in higher education sub sector. However the presented findings indicate a contrasting 
phenomenon in which despite their larger number private higher education institutions have been enrolling fewer students than public institutions. This implies that the role of private sector in helping the existing public sector in widening education access is still low and therefore needs close attention of the stakeholders to ensure that PPPs widen higher education opportunities.

The surge of private universities and university colleges as a result of both higher education policy and PPPs has had an implication on education quality. Some universities have enrolled students when they do not have capacity in terms of staffing and infrastructure. As a result graduates from these universities are superficially prepared and do not fit the job market. Empirical evidence further show that some universities enroll students without enough capacity to accommodate them in the available educational infrastructure. This calls for policy measures that take on board seriously the issue of policy compliance before the establishment of a university or a programme. Indeed, Tanzania Commission for Universities (TCU) has a role to play in making sure that no university whether public or private becomes a degree mill. TCU can and should do more than it currently does. It is encouraging to note that TCU has started to take stern measures against all public and private higher learning institutions found to be wanting in some critical aspects. For example, TCU has announced to suspend 2016/17 undergraduate admissions for some or all programmes in six higher learning institutions including the University of Dodoma (UDOM), State University of Zanzibar (SUZA), International Medical and Technological University (IMTU), University of Bagamoyo (UoB), St. Joseph University College of Engineering (SJUCET), and St. Francis University College of Health and Allied Sciences (SFUCHAS) (TCU 2016c: 6).

\section{Conclusions}

This paper aimed at examining the impact of public private partnership in Tanzania higher Education institutions on access to and quality of education provided. It gathered data from published secondary academic sources as well as from primary documents from TCU and some private higher learning institutions. In view of the analysis made the paper concludes that public private partnership in Tanzania higher education has had a positive impact on creating more opportunities for accessing higher education. It has more significantly helped reduce gender gap in student enrolment as private higher learning institutions enroll a higher proportion of female student than the public institutions. That notwithstanding, increase in access to higher education through an increase in student enrollment hasn't meant that there have been adequate opportunities in private institutions for access to diverse and unique degree programmes and courses. Furthermore, PPPs have not helped improve the quality of education especially in private institutions due to inadequate number and qualifications of members of academic staff teaching in these institutions. Similarly, although the number of private higher education institutions has tremendously increased, public higher education institutions continue to be significant in that they enroll a large number of students and are heavily relied upon by private institutions for academic staff and, sometimes, education programmes offered.

Given the low enrollment rate in Tanzania higher education, PPPs' role in expanding opportunities in higher education need to be revisited and corrective measures taken. 
This is because if institutions are established without a clear enrolment threshold, there is a danger of compromising quality of education provided and having institutions that have little contribution to education access. This implies that no matter how good PPPs are, they require proper arrangement that need to be done in line with good watchdogs or organizations that closely asses the ability of institutions providing such education without compromising the quality of output from these universities.

\section{Authors' contributions}

The main author of this paper, SJM collected secondary and primary data, did the analysis and wrote the methodology, basic facts about higher education in Tanzania, results and discussion, policy implications and the conclusion sections. The co-author, JP, wrote the introduction, methodology, literature review sections, and some portions of the results and discussion section. Both authors read and approved the final manuscript.

\section{Author details}

${ }^{1}$ Department of Educational Planning and Administration, Faculty of Education, Mkwawa University College of Education, P.O. Box 2512, Iringa, Tanzania. ${ }^{2}$ Department of History, Political Sciences and Public Administration, and Development Studies, Mkwawa University College of Education, P.O. Box 2512, Iringa, Tanzania.

\section{Acknowledgements}

The authors express thanks to the anonymous reviewers for their insightful and constructive comments.

\section{Competing interests}

The authors declare that they have no competing interests.

Received: 21 May 2016 Accepted: 14 November 2016

Published online: 24 November 2016

\section{References}

AMUCTA. 2015. Prospectus 2015/2016. Tabora: AMUCTA. http://www.amucta.ac.tz/downloads/PROSPECTUS\%2020152016.pdf. Accessed 18 July 2016.

Awidi IT. 2014. Repositioning budget-constrained universities as third-generation universities. Educ Rev, November 24. http://er.educause.edu/articles/2014/11/repositioning-budgetconstrained-universities-as-thirdgeneration-universities. Accessed 2 Jan 2016.

Backiny-Yetna, Prospere, and Quentin Wodon. 2009. Comparing the performance of faith-based and government schools in the Democratic Republic of Congo. In Emerging evidence on vouchers and faith based providers in education: Case studies from Africa, Latin America and Asia, ed. Felipe Barrera-Osorio, and Harry Anthony Patrinos. Washington DC: International Bank for Reconstruction and Development/The World Bank.

Bano, Masooda. 2008. Public private partnerships (PPPs) as 'anchor' of educational reforms: lessons from Pakistan. Background paper prepared for the Education for All Global Monitoring Report 2009. http://datatopics.worldbank.org/hnp/ files/edstats/PAKgmrpap08.pdf. Accessed 19 July 2016.

Barnett, Ronald. 1992. Improving higher education: Total quality care. Bristol: Open University Press.

Barrera-Osorio, Felipe, Harry Anthony Patrinos, and Quentin Wodon. 2009. Public-private partnerships in education: An overview. In Emerging evidence on vouchers and faith-based providers in education: Case Studies from Africa, Latin America, and Asia, ed. Felipe Barrera-Osorio, Harry Anthony Patrinos, and Quentin Wodon. Washington DC: The International Bank for Reconstruction and Development/The World Bank.

Biswalo, P.M. 1985. A study of the impact of the musoma resolution on student personnel services at the University of Dar es Salaam. Utafiti VII 2: 75-81.

Brans, Bo-Joe. 2011. Public-private partnerships in education: Analysing PPPs as a policy tool for Universal Secondary Education in Uganda. MSc Dissertation, Graduate School of Social Sciences, Universiteit van Amsterdam. https://educationanddevelopment.files.wordpress.com/2008/04/ppps-in-uganda-bo-joe-brans.pdf. Accessed 5 Jan 2016.

Bray, Mark. 1999. The private costs of public schooling: Household and community financing of primary education in Cambodia. Paris: UNESCO. http://unesdoc.unesco.org/images/0011/001176/117632E.pdf. Accessed 9 Apr 2016.

Brock-Utne, Birgit. 2003. Formulating higher education policies in Africa: the pressure from external forces and the Neoliberal Agenda. Journal of Higher Education in Africa 1(1): 24-56.

Chediel, R.W., N. Sekwao, and P.L. Kirumba. 2000. Private and community schools in Tanzania (Mainland). Paris: International Institute for Educational Planning/UNESCO. http://unesdoc.unesco.org/images/0012/001224/122460E.pdf. Accessed 6 May 2016.

Education International. 2009. Public private partnerships in Education. http://download.ei-ie.org/docs/IRISDocuments/ Research\%20Website\%20Documents/2009-00086-01-E.pdf. Accessed 5 Jan 2016.

Ellis, Carolyn, Tony E. Adams, and Arthur P. Bochner. 2011. Autoethnography: An Overview. Forum: Qualitative Social Research 12(1): 273-290.

ETU. 2016. Our courses. http://etu.ac.tz/courses.htm. Accessed 19 July 2016.

European Commission. 2013. Funding of education in Europe 2000-2012: The impact of the economic the economic crisis. Eurydice Report. Luxembourg: Publications Office of the European Union. doi:10.2797/50340. Accessed 2 Jan 2016.

Grisay, Aletta, and Lars Mählc. 1991. The quality of education in developing countries: A review of some research studies and policy documents. http://unesdoc.unesco.org/images/0008/000886/088661eo.pdf. Accessed 1 Jan 2016. 
Higher Education Students'Loans Board. 2016. Guidelines and criteria for issuance of students'loans and grants for the 2016/2017 academic year. http://olas.heslb.go.tz/downloads/PUBLISHED_GUIDELINES_2016_17.pdf. Accessed 13 July 2016.

Ishengoma, J.M. 2007. The debate on quality and private surge: a status review of private Universities and Colleges in Tanzania. Journal of Higher Education in Africa 5(2-3): 85-109.

Johnson, Megan Patricia. 2011. Women's Access to Higher Education in Tanzania: A qualitative study." PhD Thesis, University of lowa. University of lowa. http://ir.uiowa.edu/cgi/viewcontent.cgi?article=2618\&context=etd. Accessed 1 Nov 2016.

Konings, Piet. 2002. University Students' Revolt, Ethnic Militia and Violence during Political Liberalization in Cameroon. African Studies Review 45(2): 179-204.

Kuhanga, N.H.A. 2006. Private higher education in Tanzania. In Growth and expansion of private higher education in Africa, ed. N.V. Varghese, 167-202. Paris: IIEP.

Kyule, Alexander, Maureen Kangu, Phillip Wambua, Bernadette Mutinda, and Stephen Kamau. 2014. Strategizing on cost: effect of part time lecturers on University Education in Kenya. Prime Journal of Social Science 3(2): 603-607.

Linder, Stephen H., and Pauline Vaillancourt Rosenau. 2000. Mapping the Terrain of the public-private policy partnership. In Public-Private policy partnerships, ed. Pauline Vaillancourt Rosenau. Cambridge and London: The MIT Press.

Machira, Polycarp. 2016. Thousands of students face expulsion. The Guardian, May 26. http://ippmedia.com/news/thousands-students-face-expulsion. Accessed 16 July 2016.

Makulilo, Victoria Boniface. 2012. The proliferation of private universities in Tanzania: quality compromised? Wudpecker Journal of Educational Research 1(4): 51-66.

Malik, Allah Bakhsh. 2010. Public-Private Partnerships in Education: Lessons Learned from the Punjab Education Foundation. Metro Manila: Asian Development Bank. http://www.adb.org/sites/default/files/publication/27494/ppp-educationpunjab.pdf. Accessed 2 Jan 2016.

Mgaiwa, Samson J. 2015. Institutional constraints affecting quality assurance processes in Tanzania Private Universities. Paper Presented at the 5th East African Higher Education Quality Assurance Forum: Enhancing Quality in Higher Education to Strengthen Students, Nairobi, Kenya, 4-8 May.

Ministry of Education, Science and Technology. 2016. Taarifa kwa Umma: Kuhusu Wanachuo Waliokuwa Wanasoma Stashahada Maalum ya Ualimu katika Chuo Kikuu cha Dodoma. July 19. http://www.moe.go.tz/index. php?option=com_content\&view=article\&id=1853:tangazo\&catid=1:latest-news. Accessed 19 July 2016

Mkude, Daniel, Brian Cooksey, and Lisbeth Levey. 2003. Higher education in Tanzania: A case study. Oxford and Dar es Salaam: James Currey and Mkuki na Nyota.

Mora, JoseGines. 2007. Public-private partnerships in Latin America: A review based on four case studies. In Mobilizing the Private Sector for Public Education: A view from the trenches, ed Harry Anthony Patrinos and Shobhana Sosale, 37-64. Washington, D.C.: The World Bank.

Mugabi, H. 2012. The Role of Private Universities in the Provision of Higher Education in Uganda: growth and Challenges. Africa Education Review 9(2): 213-229.

Mulokozi, E. 2012. Students'satisfaction with academic services offered by private universities in Tanzania. MEMA Dissertation. University of Dar es Salaam.

Munene, Ishmael I. 2009. Anticipated developments: east Africa's Private Universities and Privatisation of Public Universities in the Global Context. Africa Education Review 6(2): 254-268.

Njozi, H.M. 2016. The Mission of the Muslim University of Morogoro in Tanzania: Context, Promises, and Challenges. In Muslim Institutions of Higher Education in Postcolonial Africa, by Mbaye Lo and Muhammed Haron, ed. M. Lo, and M. Haron, 95-105. Hampshire: Palgrave Macmillan.

Nyahende, Veronica R. 2013. The success of students' loans in financing higher education in Tanzania. Higher Education Studies 3(3): 47-61.

Oketch, Moses O. 2003. The growth of Private University education in Kenya: the promise and challenge. Peabody Journal of Education 78(2): 18-40.

Patrinos, Harry Anthony, and Shobhana Sosale. 2007. Public-private partnerships in education." In Mobilizing the private sector for public education: A view from the trenches, by Harry Anthony Patrinos and Shobhana Sosale, 1-9. Washington, D.C.: The World Bank.

Patrinos, Harry Anthony, Felipe Barrera-Osorio, and Juliana Guáqueta. 2009. The role and impact of public-private parterships in education. http://www.ungei.org/resources/files/Role_Impact_PPP_Education.pdf. Accessed 20 Dec 2015.

Robertson, Susan L., Karen Mundy, Antoni Verger, and Francine Menashy. 2012. An Introduction to Public Private Partnerships and Education Governance. In Public private partnerships in education: new actors and modes of governance in a globalising world, ed. Susan Robertson, Karen Mundy, Antoni Verger, and Francine Menashy. Cheltenham: Edward Elger.

RUCU. 2014. Prospectus for the Academic Year 2014/2015. Iringa: RUCU. http://rucu.ac.tz/matangazo/PROSPECTUS_2014. pdf. Accessed 17 July 2016.

RUCU. 2015. Selected Students for Postgraduate Studies Academic Year 2015/16. http://rucu.ac.tz/index.php/news/85updated-list-for-selected-candidates-for-postgraduate-studies.html. Accessed 19 July 2016.

Rugambuka, Innocent Buberwa. 2008. The performance of higher education students'loan scheme in Tanzania: The stakeholders'views. MPhil Thesis. University of Oslo. https://www.duo.uio.no/bitstream/handle/10852/31073/ Rugambuka.pdf? sequence=1. Accessed 11 July 2016 .

Sall, Ebrima. 2004. Alternative models to traditional higher education: market demand, networks, and private sector challenges. Journal of Higher Education in Africa 2(1): 175-210.

Scheerens, Jaap. 2011. Measuring educational quality by means of indicators. In Perspectives on Educational Quality: Illustrative Outcomes on Primary and Secondary Schooling in the Netherlands, ed. Jaap Scheerens, Hans Luyten, and Jan van Ravens, 35-50. Dordrecht: Springer.

SEKOMU. 2014. Prospectus, 2014/2015-2016/2017. Lushoto: SEKOMU. http://www.sekomu.ac.tz/images/2014_2015/Prospectus/SEKOMU-PROSPECTUS-2015.pdf. Accessed 18 July 2016. 
Simon, P. 2010. Academic Staff Capacities and Utilisation in Private Universities in Tanzania. MEMA Dissertation, University of Dar es Salaam.

SJUT. 2009. Background - the Mazengo Campus of St John's University of Tanzania. http://www.sjut.ac.tz/whyfances.php. Accessed 18 July 2016.

SJUT. 2014. Combined Prospectus for all Sites and Courses, 2014-2015. Dodoma: Office of the Deputy Vice Chancellor Academic. http://www.sjut.ac.tz/Prospectus/SJUTProspectus2014-2015.pdf. Accessed 17 July 2016.

Sokoine University of Agriculture. 2016. University Profile. July. http://sua.ac.tz/index.php/about-us/university-profile. Accessed 1 Nov 2016.

TCU. 2012. Tanzania Commission forUniversities Accreditation. www.tcu.tz/universities/accreditation.php.rect. Accessed 10 May 2016.

TCU. 2014. Quality Assurance General Guidelines and Minimal Standards for Provision of University Education in Tanzania. Dar es Salaam: TCU. http://www.tcu.go.tz/images/pdf/QA\%20GUIDELINES\%20AND\%20STANDARDS.pdf. Accessed 9 Apr 2016.

TCU. 2015a. Quality assurance general guidelines and minimal standards for provision of University Education in Tanzania, 2nd ed. Dar es Salaam: TCU.

TCU. 2015b. Students Enrolled in Universities and University Colleges 2009/2010-2013/2014. http://www.tcu.go.tz/ images/documents/Enrolment_2005_2015.pdf. Accessed 1 Nov 2016.

TCU. 2016a. List of University Institutions in Tanzania as of 22nd February, 2016. http://www.tcu.go.tz/images/documents/RegisteredUniversity.pdf. Accessed 1 Nov 2016.

TCU. 2016b. The TCU rolling strategic plan 2016/2017-2020/2021. Dar es Salaam: TCU.

TCU. 2016c. Undergraduate Admission Guidebook for Higher Education Institutions in Tanzaniaor Applicants with Form Six Qualifications, 2016/2017. Dar es Salaam: TCU. http://tcu.go.tz/images/documents/Undergraduare_Admission_ Guidebook_2016_2017.pdf. Accessed 22 July 2016.

TCU. no date. Students enrolled in Universities and University Colleges by Programme Categories 2004/2005-2010/2011 . http://www.tcu.go.tz/images/pdf/Enrollment\%20by\%20category.pdf. Accessed 6 May 2016.

TEKU. 2015. Postgraduate Prospectus for 2015/2016. Mbeya: TEKU. http://teku.ac.tz/matangazo/postgraduate2016.pdf. Accessed 18 July 2016.

UNESCO. 2011. Tanzania Education Sector Analysis: Beyond Primary Education, the Quest for Balanced and Efficient Policy Choices for Human Development and Economic Growth. Dakar: UNESCO. http://unesdoc.unesco.org/ images/0021/002152/215247e.pdf. Accessed 9 Apr 2016.

United Republic of Tanzania. 1999. National Higher Education Policy. Dar es Salaam: Ministry of Science, Technology and Higher Education. http://www.tzonline.org/pdf/nationalhighereducationpolicy.pdf. Accessed 30 Oct 2016.

United Republic of Tanzania. 2010. Higher Education development programme, 2010-2015: Enhanced relevance, access and quality in higher education. Dar es Salaam: Ministry of Education and Vocational Training. http://www.tanzania.go.tz/ egov_uploads/documents/Higher_Education_Development_Programme_2010-2015_sw.pdf. Accessed 1 Nov 2016.

United Republic of Tanzania. 2014. Basic Education Statistics in Tanzania (BEST): National Data. Dodoma.

URT. 2009. National Public Private Partnership (PPP) policy. Dar es Salaam. http://www.tic.co.tz/media/PPP\%20Policy.pdf. Accessed 20 Mar 2016.

Varghese, N.V. 2004. Private higher education in Africa. Paris: IIEP/UNESCO.

Verger, Antoni. 2012. Framing and Selling global Education Policy: the Promotion of Public-Private Partnerships for Education in Low-Income Contexts. Journal of Education Policy 27(1): 109-130. doi:10.1080/02680939.2011.623242.

Wodon, Quentin, and Yvonne Ying. 2009. Literacy and Numeracy in Faith Based Government Schools in Sierra Leone. In on Vouchers and Faith Based Providers in Education: Case Studies from Africa, Latin America and Asia, by Felipe BarreraOsorio, Harry Anthony Patrinos and Quentin Wodon, 99-118, ed. Emerging Evidence. Washington, D.C.: International Bank for Reconstruction and Development/The World Bank.

\section{Submit your manuscript to a SpringerOpen ${ }^{\circ}$ journal and benefit from:}

- Convenient online submission

- Rigorous peer review

- Immediate publication on acceptance

- Open access: articles freely available online

- High visibility within the field

- Retaining the copyright to your article

Submit your next manuscript at $\boldsymbol{\nabla}$ springeropen.com 